\title{
LAND SUBSIDENCE CAUSED BY SOLUTION MINING IN THE MOGILNO SALT DOME
}

\author{
Grzegorz KORTAS $^{1}$, Agnieszka MAJ $^{1}$ \& Jacek DROGOWSKI ${ }^{2}$ \\ ${ }^{1}$ The Strata Mechanics Research Institute of the Polish Academy of Sciences; \\ ul. Reymonta 27, 30-059 Krakow, Poland; \\ e-mail: kortas@img-pan.krakow.pl,maj@img-pan.krakow.pl \\ 2 Inowrocław Salt Mines , Solino” SA; \\ ul. św. Ducha 26a, 88-100 Inowrocław, Poland; \\ e-mail: jacek.drogowski@solino.pl
}

\begin{abstract}
Occurrence of land surface subsidence is a result of rock salt extraction. The process is observed by geodetic measurements. On the Palędzie I salt mining field, such measurements are conducted every five years. The most recent series of measurements was carried out in 2009. The analysis of land levelling results indicated that a twin-centre subsidence is still being formed above the salt mining area. Its maximum load on the SW side of the salt dome exceeded $-100 \mathrm{~mm}$ in 1986-2009. The second subsidence centre behind the NE edge pillar is $50 \%$ smaller than the first one. Along with the extraction moving up to shallower areas of the salt bed, the rate of land surface subsidence is increasing, with the decreasing perimeter of the depression. The indicators that describe the land surface subsidence - vertical displacement of benchmarks and the caverns volume - are presented on the function of time and a parameter, determining the distance from the measurement point to the exploitation field edges.
\end{abstract}

Key words: salt domes, land subsidence, salt caverns, twin-centre trough

\section{INTRODUCTION}

The recognition of the influence of the salt bed exploitation on land surface on the basis of the coal and ore mining operations is not adequate for the description of the influence of mining operations in salt deposits, in solution mining in particular. The diversity of geological and mining conditions existing in the salt dome consists in definitely rheological 
properties of the salt medium, specific form of solution mining operations, where the range of opening is several times smaller than the height and direction of the movement of the mining operating front from the bottom to the ceiling.

The application of the physical models of the elastic-viscous medium to describe the rock salt mass (Beiley 1929, Norton 1929, Ślizowski 2006) opened the way to the general determination of the influence of soil mining on the rock mass and land surface (Kortas 2008, 2009). Consequently, a separate type of subsidence distribution was identified, including a previously unknown type of the influence of mining operations resulting in the production of a twin-centre subsidence trough. An example of that phenomenon has been observed in the distribution of the exploitation effects above the Mogilno salt dome.

The purpose of this study is to present the current state of the surface subsidence recognition above the solution mining facility in Mogilno, taking into account the observations conducted in 2009, the distribution of the subsidence with the exploitation frontage movement, and the development of long- and short-term influences. On that basis, we identified the trends of the changing rates of subsidence and the subsidence distribution, appearing in recent years.

\section{RESEARCH AREA DESCRIPTION}

The Mogilno salt dome (Fig. 1) has the shape of a flat ellipsis in a horizontal cross-section, with the salt mirror situated at ca. $250 \mathrm{~m}$ under the ground level. At ca. $600 \mathrm{~m}$, the length of the dome is $5.5 \mathrm{~km}$, and the width is ranging from $0.8 \mathrm{~km}$ to $1.5 \mathrm{~km}$. The NE dome wall is sloping at the angle of ca. $80^{\circ}$, while the opposite $\mathrm{SW}$ one at $90^{\circ}$ and more, creating overhangs. On the SE side of the salt dome, the salt ceiling is situated at the depth of 550-650 m.

The internal dome structure has been recognized primarily owing to the drilling operations along the exploitation cavern axes. In recent years, research works were conducted on the use of borehole geo-radars to determine the internal deposit structures in the Gora and Mogilno salt mines (Tadych et al. 2010). The main mass of the salt dome is made of the coarse-crystal older salt. It is contaminated by anhydrite which occurs either in dispersed or laminar forms. The transition strata are made of fine-crystal salts, with silt-anhydrite flasers and the traces of potassium-magnesium salts. The $\mathrm{NaCl}$ content determined for the particular cyclothems is ranging in the deposit from $90.0 \%$ to $98.5 \%$. As a result of halokinetic tectonic stresses, particular strata were subjected to strong, folded deformations, pressing, and wearing. Locally thick layers appear. The recorded wall angles range from $70^{\circ}$ to $90^{\circ}$, with a frequent reversal of layer sequence.

The salt rocks of the Mogilno salt dome are characterized by diverse geo-mechanical properties, deformations, and the strength of both long-term and temporary nature (Grzybowski et al. 2008). Flexibility to creep, increasing with depth, is a feature of that medium. The salt's flexibility to creep and dissolution results from the sequence of strata, mineral composition diversity, grain and crystal sizes, and natural fractioning in particular formations. 
WNW

ESE

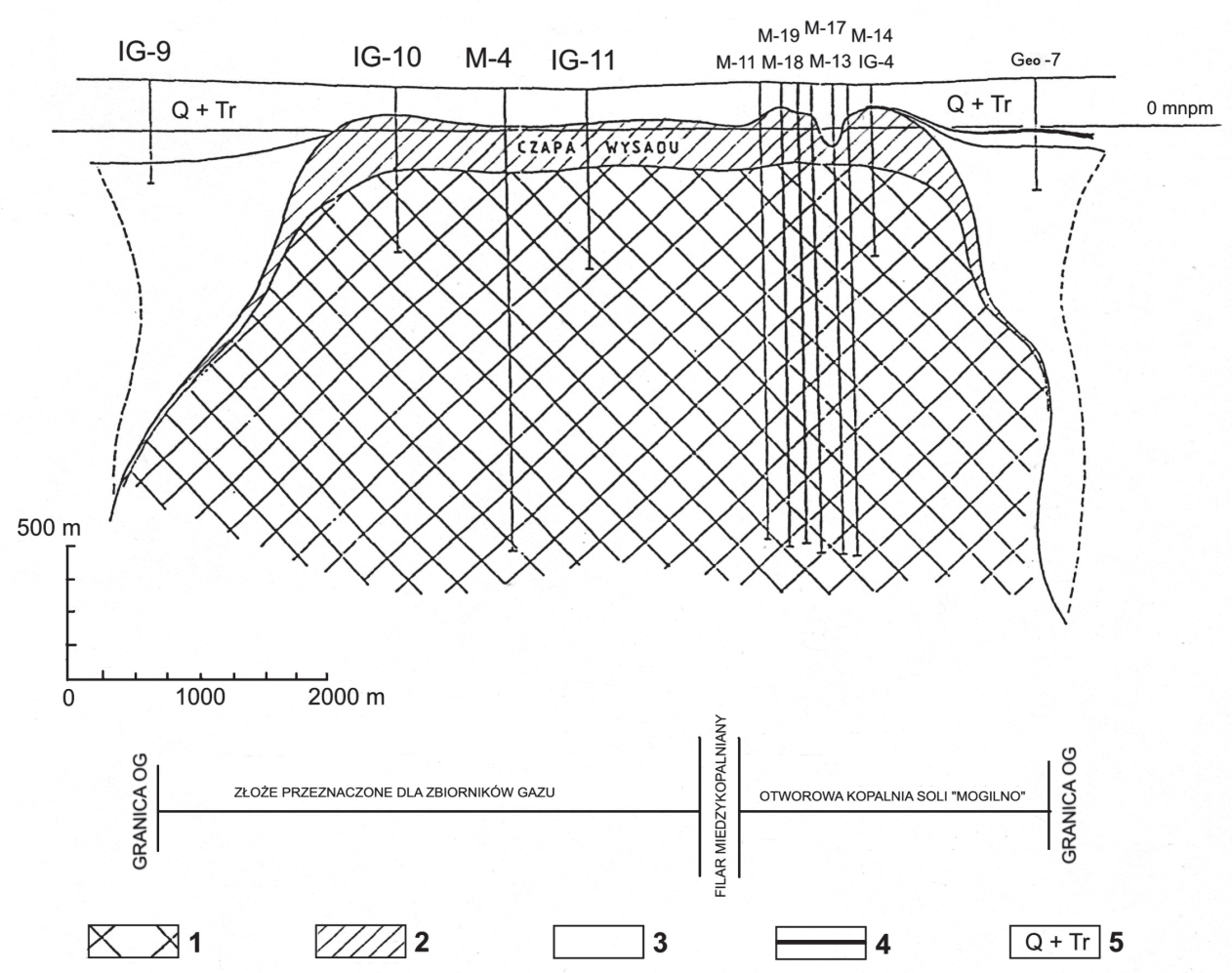

Fig. 1. Geological cross-section of the Mogilno salt dome (Szybist in: Kortas red. 2008): 1 - salt series, 2 - gypsum cap + anhydrite coat, 3 - Mesozoic, 4 - brown coal, 5 - Tertiary and Quaternary

In the SE section, the deposit has been mined by underground leaching since 1986, and a cavern gas storage facility has been situated in the NE section. The solution mining method was started at the depth of $1,400 \mathrm{~m}$ and continued up to the ceiling shelf at $400 \mathrm{~m}$. The leaching openings were set within a triangle grid of $100 \mathrm{~m}$ sides. The cavern diameters depend on cavern depths and range from $45 \mathrm{~m}$ in the lower zone to $55 \mathrm{~m}$ in the upper one on the average. On the area of the potassium-magnesium salt occurrence, the openings are locally larger. Proper shelves for conducting mining operations were left in the beds which are not useful for extraction.

Owing to the mining method, the changeability of the susceptibility to the dissolution is especially arduous. K-Mg salts and coarse-crystal halite are quicker to dissolve than the medium- and fine-crystal rock salts. $\mathrm{K}-\mathrm{Mg}$ salts are still dissolving even in the fully $\mathrm{NaCl}$ saturated brine. They create the so-called heavy potassium-magnesium alkalis. Vertical bedding is favourable for alkali dropping and light brine rise. Consequently, constantly active 
leaching places occur, with the development of unintended connections between caverns. Those are the reasons of uneven, non-cylindrical cavern shaping.

The cavern geometry is identified on the basis of the sonar measurements. Owing to the inaccessibility of certain leached out areas for taking measurements, within the so-called acoustic grey zones, the cavern volume is determined mainly on the basis of the extraction output data. Despite the breaching pillar space, considerable resistant virgin masses are preserved in the rock mass between the caverns. The mining ratio, or the proportion between the cavern volume and space determined by the mining field boundaries (excluding the edge pillars and the mine's ceiling shelf), is estimated at 0.23 in the Mogilno Salt Mine. That value is similar to the indicators obtained in underground room-and-pillar salt mining conducted in the Kłodawa Salt Mine, as well as in the Solno and Wapno salt mines exploited in the past. With a similar use of mining ratio, the geo-mechanical conditions are more beneficial in the salt mines using the solution method than in the case of the underground dry extraction. That is caused of body rock support by brine under its hydrostatic pressure, as well as the leaching, non explosive mining method effects.

\section{THE RESEARCH METHOD}

Convergence, uplift of cavern bottoms, and land surface displacements are measurable effects of geo-mechanical actions that affect the rock mass during salt mining. Since the caverns are not separated, the convergence of cavern environment deformations has not been studied yet. However, the measurements of displacemens within the mining area have been regularly taken. Six observations by the precise levelling method, class II, were conducted between the start of the field mining operations in 1986 and the last series of measurements taken in 2009 , with the average error of $\pm 0.7 \mathrm{~mm} / \mathrm{km}$. The number of benchmarks observed since 1986 was reduced, although new ones were set up as well. It is estimated that the network observation capability indicator reached 0.63 , in the scale from 0 to 1.0 , based on the criteria determined in the literature (Maj 2004).

In the case of the observation of slowly increasing displacements, the time gap between observations is selected in respect of the accuracy of measurements. The subsidence determination error in geodetic measurements increases with the length of levelling sequences and the sum of levelling deviation squares determined for the grid mesh, although the reliability of subsidence measurements also depends significantly on the stability of link points. When analyzing the influence of the Wieliczka Salt Mine on the ground surface, Szewczyk (2008) appraised the average subsidence height error at $\pm 5 \mathrm{~mm}$. The author stated, however, that, omitting the errors between link points and stable points, the accuracy of height determination by the precise levelling method, after a measurement result adjustment, can reach $\pm 0.5 \mathrm{~mm}$ on the average (oral communication). However, taking into account the diversity of link-point selection in the levelling grid applied in Mogilno and the uncertain stability of link points, we can assume that the upper error limit of subsidence height determination does not exceed $\pm 2 \mathrm{~mm}$. 
The distribution of subsidence on the Palędzie I mining field in 1986-2009 is shown in Figure 2. Subsidence areas do not exceed $-105 \mathrm{~mm}$. The subsidence of $-148 \mathrm{~mm}$ appeared above the southern salt dome wall, but it was omitted in the presentation of the subsidence distribution in this study, owing to the incidental increase of subsidence recently. The maximum average the subsidence rate was $-4.8 \mathrm{~mm} /$ year.

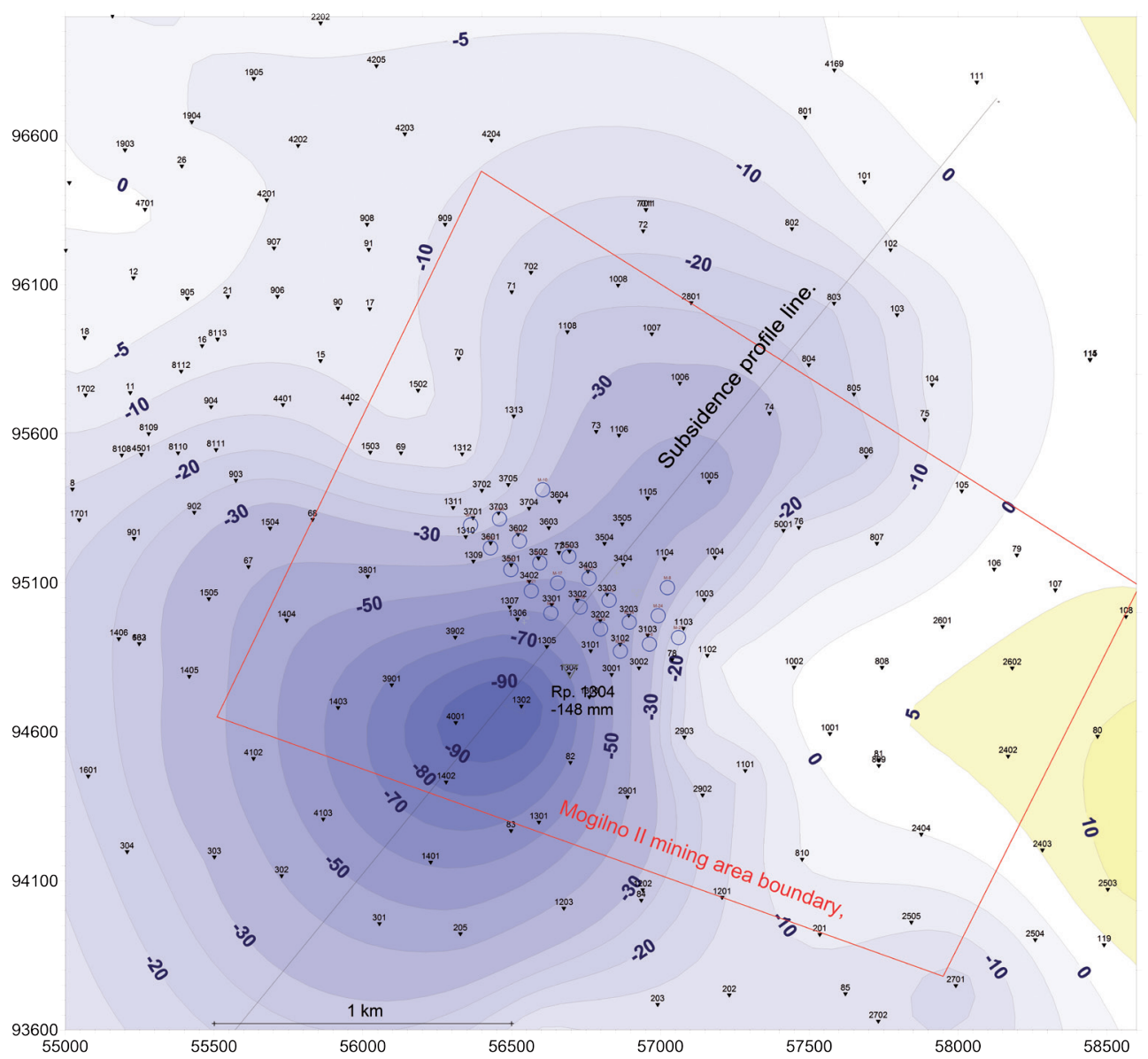

Fig. 2. Land subsidence in 1986-2009 (milimiters), with the locations of mining openings

The distribution of the subsidence in 2004-2009, presented on Figure 3, shows that it was mainly the area adjacent to the SW salt dome wall which subsided in that period. The maximum subsidence reached $-51 \mathrm{~mm}$, and the average rate of maximum subsidence amounted to $-10 \mathrm{~mm} /$ year in that period. 


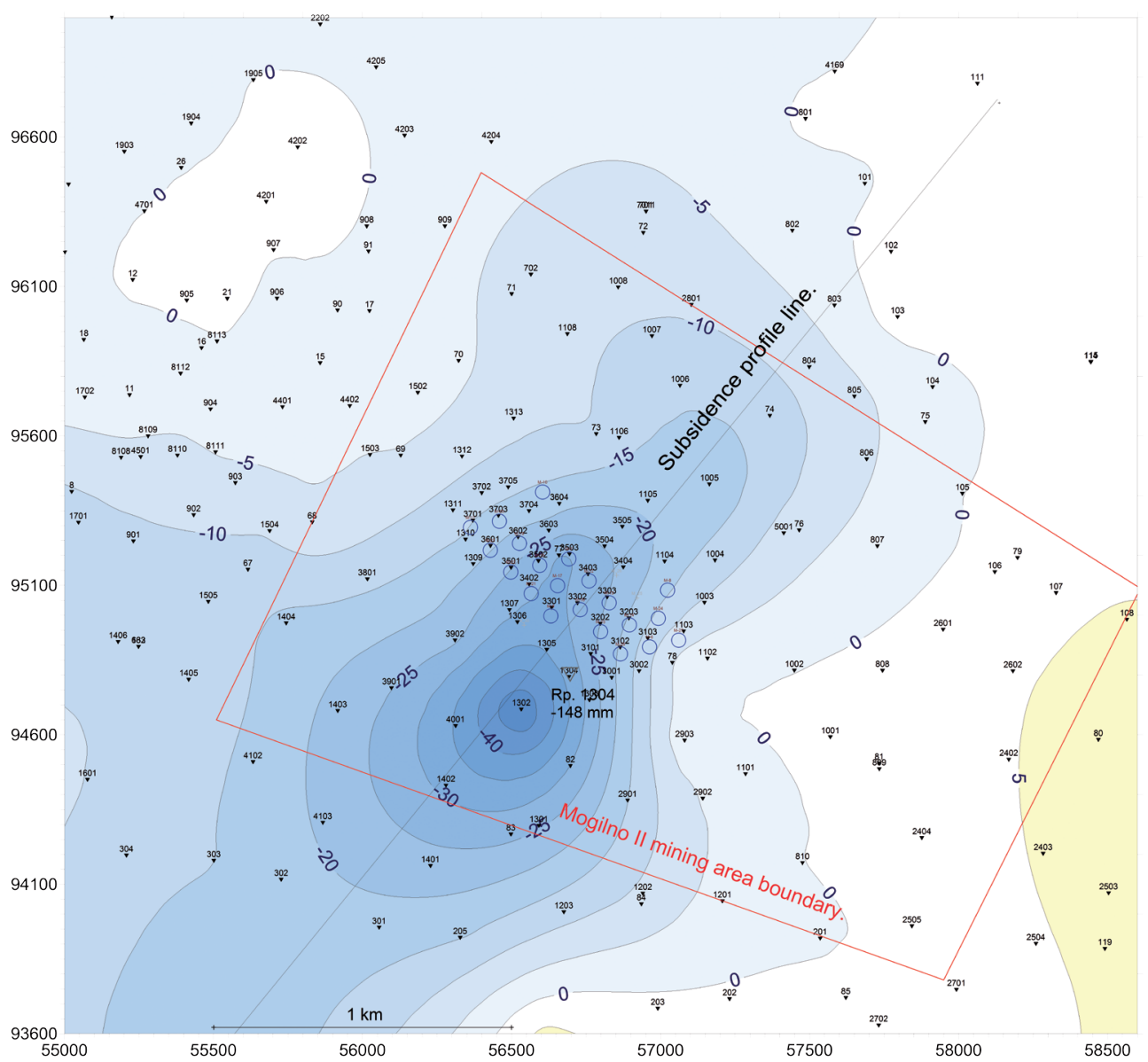

Fig. 3. Increase of the land subsidence trough in 2004-2009 (milimiters)

The Horizontal displacements were dominating the component movements in the cavern environment. The Land surface subsidence is the result of such a rock mass movement dissipation. Owing to the shape of the vertical cross-section of the mine structure and salt dome, the range of the effects moving in the eastern direction is the smallest, and we can estimate it at $400 \mathrm{~m}$. In the western direction, however, the zero isoline of the subsidence appears outside the edge pillar, at a distance not exceeding $1,000 \mathrm{~m}$, within the influence zone of the underground cavern gas storage facility. The uplift effect measured on about a dozen of the benchmarks located on the eastern section of the subsidence trough (Figs 2, 3) can indicate that the link points of the levelling measurements were not stable or, which is also probable, the analysts observed the salt dome uplift activity caused by the mining operations. However, the stability of the observation grid link points requires clarification first of all. 
The variations of the land subsidence distribution in 1986-2009 are illustrated by a set of profiles specified for the direction which is perpendicular to the longitudinal axis of the salt dome (Fig. 4).

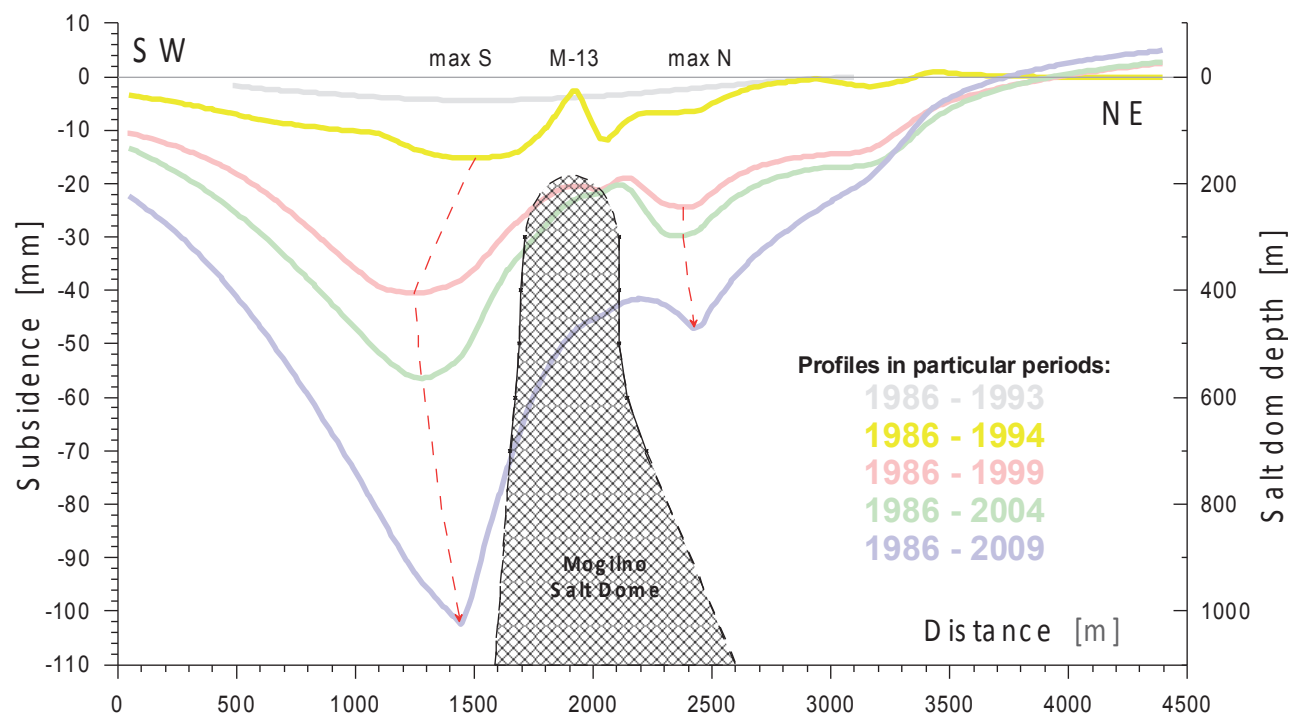

Fig. 4. SW-NE profiles of land subsidence in 2009

The analysis of the subsidence distribution above the solution mining area in Mogilno indicates the following:

- the distribution of subsidence does not create a regular trough, but rather a twin-centre trough is shaped along the axis which is perpendicular to the longer side of the mining field;

- the maximum subsidence ( $\max \mathrm{S}$ and $\max \mathrm{N}$ on Figure 4) occurs on the SW side of the salt dome, $400 \mathrm{~m}$ from the field centre, and that distance decreased in recent years;

- the second centre, with smaller subsidence, is located in the same distance from the field centre but in the opposite direction (NE); that distance increased in recent years;

- the range of effects on the SW side is larger than in the NE side, and it reaches the distance double of the mining depth.

However, the present geophysical recognition of the salt dome boundaries is not accurate enough. Generally, the edge pillars are wider on the NE side than on the SW side (Fig. 4), therefore, the consequences of possible leaching out of the deposit at the SW border can be reflected in the form of the land subsidence.

Model studies explain that the twin-centricity of the subsidence trough is the result of the slim vertical mining structure and the more conspicuous it is the higher is the technologic pressure. The technologic pressure applied in mining is useful for overcoming the extracted brine's flow resistance. The shift of the mining frontage up to the ceiling section of the deposit allows for the reduction of the pressure applied. 
Consequently:

- the rock mass uplift gets smaller in the central part of the subsidence trough,

- the pressure in the cavern decreases, and the same with the hydraulic support on the body rock in the lower extracted section of the deposit,

- convergence increases in the lower section of the deposit,

- land surface subsidence height increases, especially close to the boreholes field.

The model studies conducted in 2011 (Kortas et al. 2011) indicated that expanding deformations are present in the close vicinity of the caverns. In the case of excessive process pressures, those deformations could cause local fracture in the rock mass. The difference between the volumetric convergence of the caverns and the subsidence trough volume corresponds to the increase of the rock mass volume in the zone affected by the mining operations. Thus, the smaller the trough volume the larger volumetric deformations can be expected. They reach maximum values if no land surface subsidence occurs together with cavern convergence.

\section{DISCUSSION}

The trends of rock mass movement and land trough shaping can be determined on the basis of benchmark lowering observations in time. The benchmark lowering above the solution workings during the 1986-2009 period is presented on Figure 5.

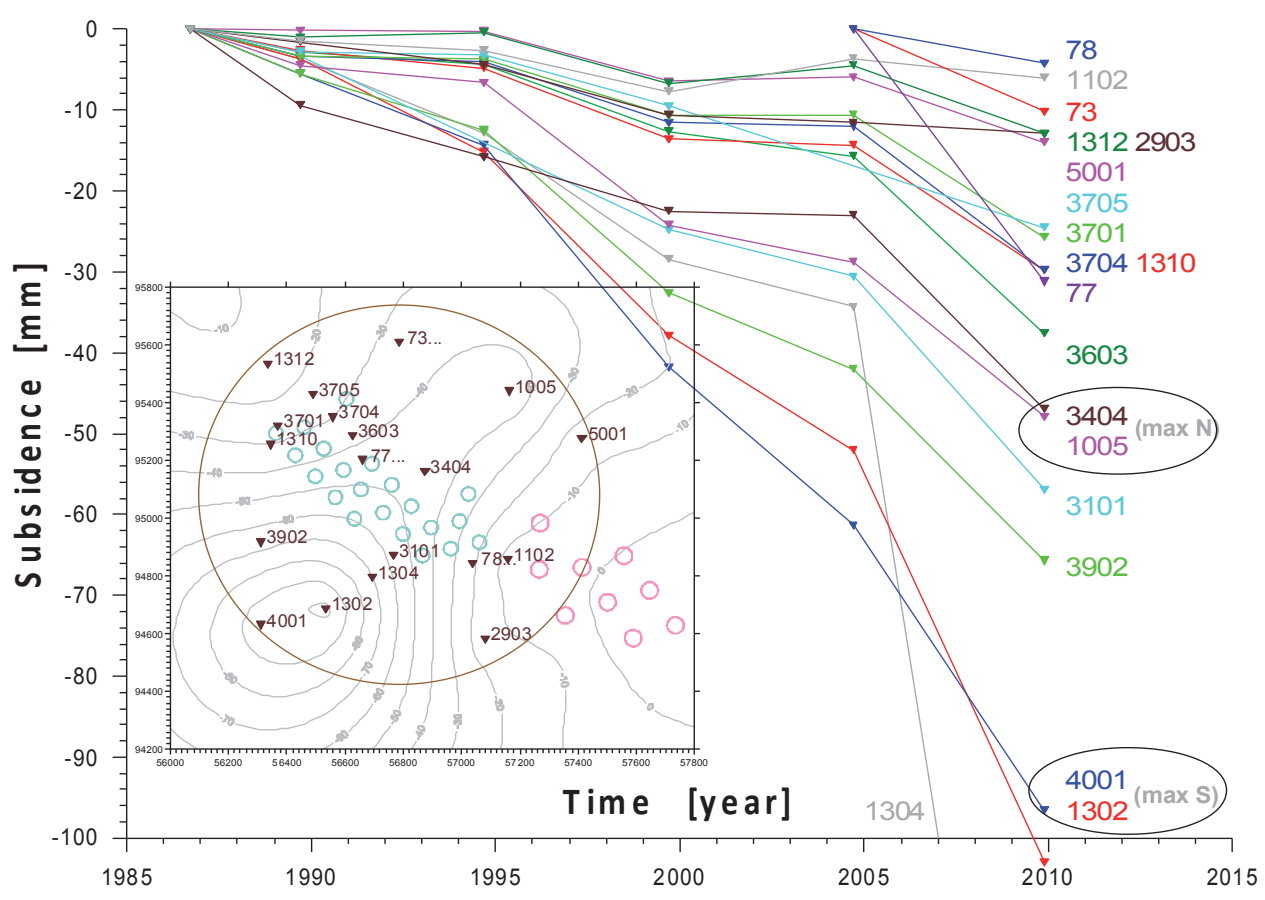

Fig. 5. Benchmark lowering in the central part of the subsidence trough 
Observations revealed a non-linear increase of subsidence. On that background, short temporary abrupt subsidence rate changes are observed as well. Those were rather caused by the consequences of the methods of linking the grid and its equalization than any geological or mining aspects, which was better visible on the areas subjected to bigger subsidence. The dependence of the subsidence on time is the increasing function, with the trend which is similar to large and small subsidence heights. Therefore, the trend is characterizing the behaviour of the rock mass and land surface areas affected by the mining operations.

The relationship between land subsidence and time can be expressed by the following exponential function:

$$
w(t)=w_{0}[\exp (C \Delta t)-1]
$$

where $\Delta t$ (year) is the time increase since the start of the mining operations in 1986, and the $C$ (1/year) parameter increase with the distance between the benchmarks and the mining field boundaries. The parameter $w_{0}=-20 \mathrm{~mm}$ can be associated with the average extraction intensity. Figure 6 shows the graphs of function (1) for several values of parameter $C$.

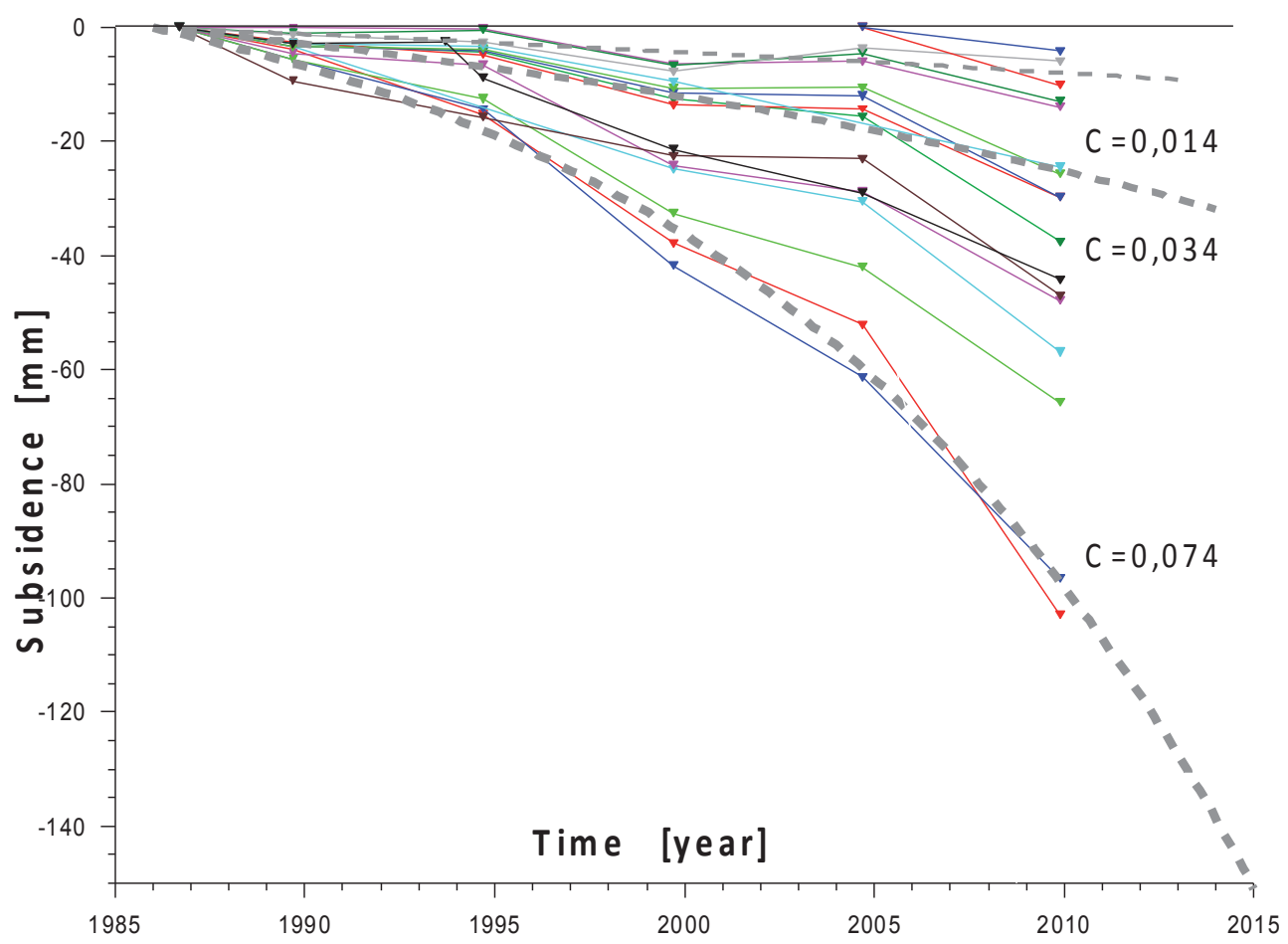

Fig. 6. Benchmark lowering rate trend 
The proportion of the trough volume $V_{N}(t)$ to the workings' volume $V_{K}(t)$ is the coefficient of the workings' influence on the affected land surface.

The trough volume in the function of time $V_{N}(t)$ was estimated on the basis of the subsidence observations. That is approximated by the following function, similar to (1):

$$
f=V_{N}(t)=0.085 \mathrm{mln} \mathrm{m}^{3}[\exp (C \Delta t)-1]
$$

where $V_{N}(1)=5,100 \mathrm{~m}^{3}$ is the increase of the trough volume subsidence in the first year of the mining operation, and the parameter is $C=0.061 /$ year.

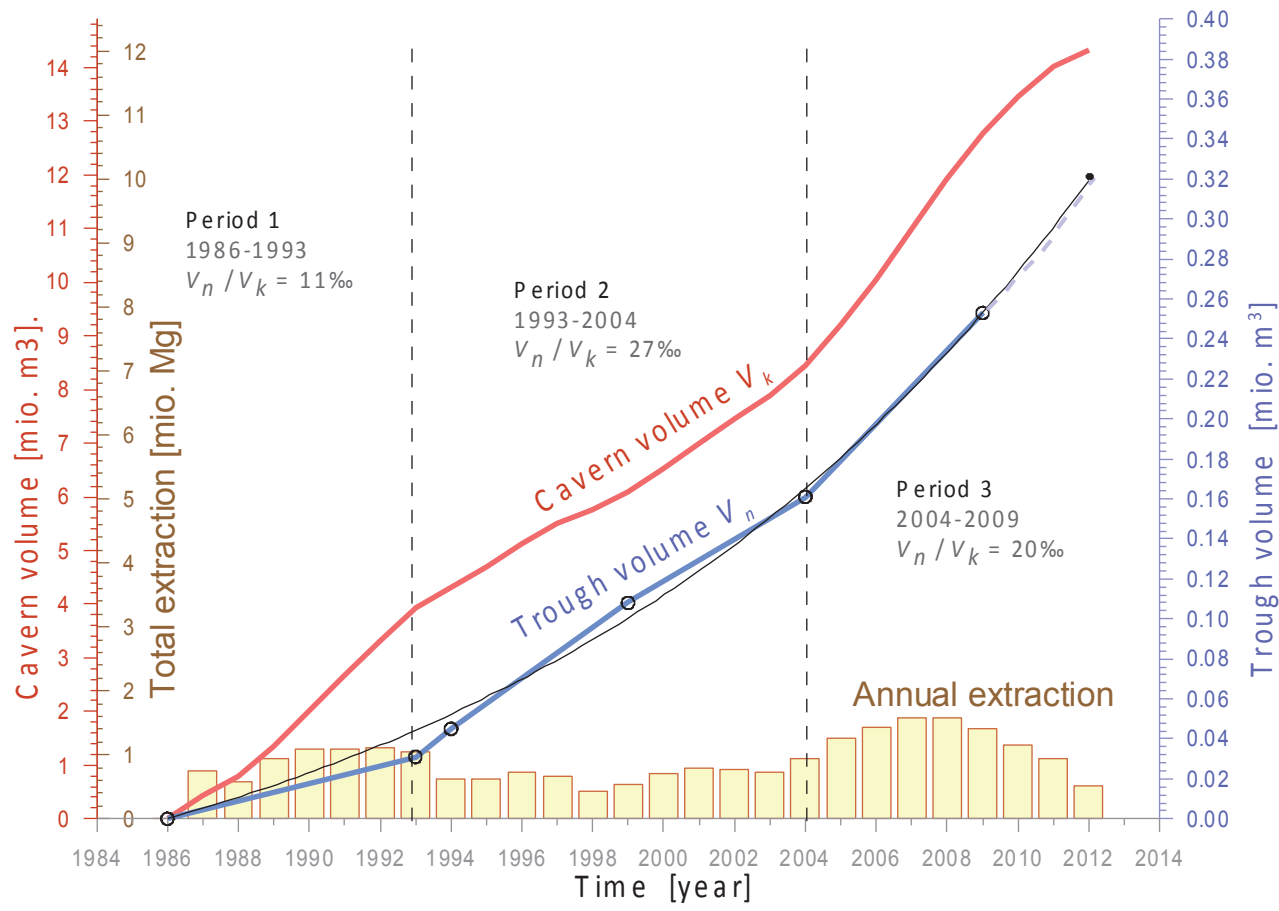

Fig. 7. Extraction, caverns and trough volumes in the time function

The cavern volume $V_{K}(t)$ was determined by assuming the calculation coefficient of $\varphi=1.68 \mathrm{Mg} / \mathrm{m}^{3}$, expressing the proportion of the workings' volume to the extracted mineral volume. Generally, three mining periods were distinguished: 1986-1993, 1993-2004, and 2004-2009 (Fig. 7). The estimated proportion of the trough volume to the cavern volumes reached the following values in the respective periods: $11 \%$, $17 \%$, and $20 \%$. The subsidence trough volume increase rate was still small: $V_{N} / V_{K}=0.321 \mathrm{Mm}^{3} / 14.4 \mathrm{Mm}^{3}=22.3 \%$. The increasing caverns' volume was the main cause of the land subsidence rate but their 
distribution in the last period was the result of the extraction of the upper part of the salt dome. The trend stability indicates that in the future we can expect further subsidence rate increases, bigger on the mining field area and surrounding lands, smaller on farther outside these areas.

The stability of the land surface subsidence trend, specified by equation (2), would lead to a considerable depression on the land surface in a longer period. The increase of subsidence rates should slow down after discontinuation of deposit exploitation.

\section{CONCLUSIONS}

1. The distribution of subsidence in 1986-2009 formed a twin-centre trough, with the maximum subsidence of $-105 \mathrm{~mm}$ on the SW side of the mining field, which was explained mainly by the vertical slenderness of the mining field. The range of the effects identified on the SW side was larger than on the NE side, and it corresponded to the double maximum depth of the caverns.

2. The increase of the subsidence in 2004-2009 indicated a further increase of the subsidence rate, which was primarily caused by the increase of the caverns' volume.

3. The proportion between the subsidence trough volume and the cavern volume, describing the influence of the exploitation on the land surface, is presently reaching ca. $22 \%$. Small land subsidence values cause, in view of the extensive trough, that the related deformations are not harmful for ground surface.

4. The evaluation of the rock mass requires previous cavern convergence measurements which will be possible after mining operations in the caverns terminate.

\section{REFERENCES}

Bailey R.W., 1929. Creep of steel under simple and compound stresses, and the use of high initial temperature in steam power plants. The transactions of the Tokyo Sectional Meeting, World Power Conference, Tokyo, October 29-November 7, 1929; vol. 3: Power for use in transportation, better efficiency in power production, 1089-1121.

Grzybowski Ł., Wilkosz P. \& Flisiak D., 2008. Mechanical properties of rock salt from Mogilno salt dome. Gospodarka Surowcami Mineralnymi [Przegląd Solny], 24, 3/2, $141-157$.

Kortas G. (red.), 2008. Ruch górotworu w rejonie wysadów solnych. Wydawnictwo Instytutu Gospodarki Surowcami Mineralnymi i Energią PAN, Kraków.

Kortas G., 2009. Singularities of the rock mass movement during the minning of salt domes. Conference Papers, Solution Mining Research Institute - Spring 2009, Kraków, 14 marca 2009. 
Kortas G., Maj A., Flisiak D., Kortas Ł., Jagiełło W. \& Kot P., 2011. Określenie optymalnych lokalizacji oraz geometrii komór eksploatacyjnych $w$ południowo-wschodniej części złoża „Mogilno I”. GeoConsulting Kraków, IKS Solino SA [unpublished].

Maj A., 2004. Obserwacja osiadań powierzchni nad wyrobiskami w wysadzie solnym na przykładzie kopalni Kłodawa. WUG: Bezpieczeństwo Pracy i Ochrona Środowiska w Górnictwie, 9, 25-28.

Norton F.H., 1929. The Creep of Steel at High Temperatures. McGraw-Hill, New York. Szewczyk J., 2008. Kopalnia Soli „Wieliczka” - 80 lat obserwacji deformacji górniczych. Gospodarka Surowcami Mineralnymi [Przegląd Solny], 24, 3/2, 251-272.

Ślizowski J., 2006. Geomechaniczne podstawy projektowania komór magazynowych gazu ziemnego w złożach soli kamiennej. Studia, Rozprawy, Monografie - Polska Akademia Nauk. Instytut Gospodarki Surowcami Mineralnymi i Energia, 137, Wyd. IGSMiE PAN, Kraków.

Tadych J., Drogowski J., Grzybowski Ł., Kleczar M., Enghardt J. \& Bornemann O., 2010. Optymalizacja procesu eksploatacji soli kamiennej w oparciu o geologiczną interpretację pomiarów georadarem złóż soli kamiennej „Góra” i „Mogilno I”. XV Międzynarodowe Sympozjum Solne Quo Vadis Sal, Świeradów-Zdrój 21-22 października 2010 r., Polskie Stowarzyszenie Górnictwa Solnego, 62-64.

\section{Streszczenie}

Wpływy eksploatacji soli na powierzchnię terenu określane są na podstawie okresowych pomiarów niwelacyjnych. Analiza wyników tych pomiarów pozwala na kontrolowanie i prognozowanie ruchu górotworu.

Wysad solny Mogilno ma kształt wydłużonej elipsy ze zwierciadłem solnym około 250 m p.p.t. (Fig. 1). Na głębokości około 600 m długość wysadu wynosi 5,5 km, a szerokość waha się od $0,8 \mathrm{~km}$ do $1,5 \mathrm{~km}$. Ściana NE wysadu jest nachylona pod kątem ok. $80^{\circ}$, natomiast przeciwległa SW $90^{\circ}$ i więcej, tworząc przewieszenia. W SE części wysadu strop soli obniża się do 550-650 m.

Otworowa eksploatacja złoża w 1986 r. rozpoczęła się od głębokości $1400 \mathrm{~m}$ do półki stropowej na głębokości $400 \mathrm{~m}$. Otwory ługownicze założono w siatce trójkątów o bokach $100 \mathrm{~m}$. Średnice kawern zależą od głębokości, wynosząc średnio od $45 \mathrm{w}$ dolnej strefie do $55 \mathrm{~m}$ w górnej. W obszarach występowania soli potasowo-magnezowych są większe. W złożu nieprzydatnym do prowadzenia eksploatacji pozostawiono między komorami odpowiednie półki.

Pomiary przemieszczeń w strefie oddziaływania kopalni prowadzone są od $1986 \mathrm{r}$. metodą niwelacji precyzyjnej ze średnim błędem $\pm 0,7 \mathrm{~mm} / \mathrm{km}$, ostatni wykonano w $2009 \mathrm{r}$. Obniżenia terenu w latach 1986-2009 nie przekraczają -105 mm (Fig. 2). Stwierdzany w pomiarach efekt podnoszenia się terenu po stronie NE niecki osiadań wskazuje, że punkty dowiązania pomiarów niwelacyjnych nie są stałe. W latach 2004-2009 obniżał się głównie rejon przyległy do SW ściany wysadu (Fig. 3). 
Osiadania terenu wykształcają się w formie dwucentrycznej niecki z maksimami po SW i NE stronie wysadu (Fig. 4). Przyczyną osobliwego rozkładu osiadań jest smukłość formy kopalni i reżim stosowanych ciśnień technologicznych. Wyniki obserwacji ujawniają zróżnicowany zasięg wpływów eksploatacji, mniejszy w kierunku NE niż w kierunku SW, co spowodowane jest budową złoża. Zasięg ten po stronie SW wysadu osiąga dwukrotną głębokość spągu komór.

Obniżenia terenu zależą od wydobycia, a prędkość ich rośnie w czasie (Fig. 5, 6). W ciągu 25 lat określa je funkcja wykładnicza z parametrem $C: w(t)=w_{0}[\exp (C \Delta t)-1]$, gdzie $C$ jest proporcjonalne do odległości reperów od pola górniczego. Objętość niecki aproksymuje także funkcja wykładnicza: $V_{N}(t)=0,085 \mathrm{mln} \mathrm{m}^{3}[\exp (C \Delta t)-1]$, gdzie $C=0,061 /$ rok.

Wskaźnikiem oddziaływania wyrobisk na powierzchnię terenu jest stosunek objętości niecki osiadań $V_{N}$ do objętości wyrobisk $V_{K}$, proporcjonalnej do wydobycia. W latach 1986-1993, 1993-2004, 2004-2009 wskaźnik $f(t)$ osiągnął wartości 11\%o, 17\%o i 20\%o (Fig. 7).

Przyczyną wzrostu prędkości obniżeń terenu jest przede wszystkim rosnąca objętość komór. Przechodzenie strefy ługowania od dołu ku górze powoduje spadek stosowanych ciśnień technologicznych, odpowiedni do zmniejszającej się jej głębokości eksploatacji. Skutkiem tego jest zmniejszenia się podparcia hydraulicznego ścian komór. Z analizy wynika, że w następnych latach można się podziewać dalszego zwiększenia prędkości obniżeń w rejonie nadległym i przyległym do pola górniczego przy utrzymywaniu się prawie stałej prędkości obniżeń w znacznym oddaleniu od wyrobisk. 